\title{
Entrepreneurship Skills Needed by Nigerian Tertiary Institution Students and Graduates for Global Relevance
}

\author{
Dr. (Mrs.) P. E. Okoro ${ }^{1}$ \\ ${ }^{1}$ Department of Business Education, Faculty of Education, Delta State University, Abraka, Nigeria \\ Correspondence: Dr. (Mrs.) P. E. Okoro, Department of Business Education, Faculty of Education, Delta State \\ University, Abraka, Nigeria.
}

Received: February 1, 2021

Accepted: March 8, 2021

Online Published: March 15, 2021

doi:10.5430/ijhe.v10n4p247

URL: https://doi.org/10.5430/ijhe.v10n4p247

\begin{abstract}
The study examined entrepreneurship skills needed by students/graduates for global relevance. The survey research design was chosen for the study. The population of the study comprises Business Education lecturers and students from three polytechnics, four Colleges of Education and Delta State University, Abraka, all in Delta State. A sample of 110 was randomly selected comprising 53 lecturers and 57 students. Data collection was via the questionnaire which was validated by three Business Education lectures from Delta State Polytechnic Ozoro, College of Education, Agbor and Delta State University, Abraka, all in Delta State, Nigeria. In analyzing data, mean and standard deviation were used for research questions, while independent samples t-test was used to test hypotheses at 0.05 level of significance. The findings revealed that entrepreneurship skills needed by students/graduates of tertiary institutions include trade show planning, promotion and execution. Others include skills for processing inventories, gross and net profit as well as keeping debt ledgers. The findings also specified ICT skills needed by students/graduates to include skills for accessing contra vision electronic software, deleting and merging mails, keying in data, copying, pasting and inserting in appropriate locations. Also revealed in the findings are significant difference between entrepreneurship and ICT skills essential for students and those essential for graduates. On the basis of these findings, it was recommended that some of these skills should be integrated into the tertiary education curriculum so that undergraduate students could be exposed to them as early as possible.
\end{abstract}

Keywords: entrepreneurship, skills, ICT, undergraduates, tertiary institutions

\section{Introduction}

The Federal Government of Nigeria formulated the National Policy on Education 1981 and has revised it several times leading generally to the current $6^{\text {th }}$ edition of 2013. The policy has been adjudged by experts in education to be adequate. However, inadequate political will to implement the policy has been the bane of the Nigerian educational system. Overtime, there has been a vacuum between formulated policies and their implementation. Policies are made and changed at will and programmes are recklessly abandoned (Ogonor, 2019).

The Entrepreneurship Development Programme (EDP) is a significant strategy for developing human resources and growth in any nation. Entrepreneurship Education is a programme of study that has to do with imparting skills on individuals, on how to make a business successful. According to Onyeanwuna and Ogona (2019), the main goal of the Entrepreneurship Development Programme is to provide knowledge of business to people having no such knowledge, thereby making them successful entrepreneurs. This philosophy is anchored on the presumption that entrepreneurs are not only born but can be identified, trained and created (Igbongidi, 2015).

An entrepreneur is a business proprietor who provides the required capital and bears the risk involved in the business. The entrepreneur's activities in the business organization draw from the French etymology "entrepredre" which means undertaking or taking action. 
Table 1. Some Characteristics and Traits of a Successful Entrepreneur

\begin{tabular}{|c|c|c|}
\hline $\mathbf{S} / \mathbf{N}$ & Characteristics & Traits \\
\hline 1 & Self Confidence & Confidence, Independence, Individually, Optimism, \\
\hline 2 & Task result oriented & $\begin{array}{l}\text { Drive for achievement, Profit oriented, persistence, perseverance, } \\
\text { determination, hard work, drive, energy, initiative }\end{array}$ \\
\hline 3 & Risk Taker & Risk taking ability, like challenges \\
\hline 4 & Leadership & $\begin{array}{l}\text { Leadership behaviour, relating well with others, responsive to suggestions } \\
\text { and criticisms }\end{array}$ \\
\hline 5 & Originality & $\begin{array}{l}\text { Initiative, creativity, flexibility, openness of mind, resourcefulness, } \\
\text { versatility, knowledge. }\end{array}$ \\
\hline 6 & Future oriented & Foresight, perceptiveness \\
\hline
\end{tabular}

Source: Workshop on Entrepreneurship conducted in East-West centre (Honolulu, 1997).

Table 1 shows the list of characteristics and traits which an entrepreneur should possess in order to establish and develop a successful owned business. The traits are inter-related, which means that a person who is self-confident will be willing to take risk, have a foresight, be knowledgeable about the business and become a leader. There are a lot of evidence to show that entrepreneurship traits and characteristics can be acquired through various ways such as model, processes, case studies and other structured learning (Okoro and Ofishe, 2012).

\section{Entrepreneurship Skills}

Entrepreneurship skills are indispensable for the economic survival of both students and graduates. According to Mgbonyebi and Olaniyi (2019), Educating people on the need for making their own business decisions, acquiring some basic vocational skills and using them with the knowledge gained in school is the bedrock of economic empowerment and development which is urgently needed. Information and communication technology which is one of the entrepreneurship skills is a veritable and essential tool in Entrepreneurship education all over the world. Okereke and Okoroafor (2011) assert that entrepreneurship skills have been acknowledged worldwide as the pertinent and rewarding tools for job creation, self-employment and economic survival of any nation.

Effective and efficient skills development systems which connect education to entrepreneurship skills acquisition can help a nation sustain productive growth and development and when improved upon, can lead to creation of good jobs which in turn enhances the people's standard of living. Ademiluyi (2007) defines entrepreneurship skills as business skills acquired by an individual to be able to function effectively as an entrepreneur in the unstable business environment or in self-employment.

Demers (2014), Patel (2015), Ikeanyionwu and Ekwe (2013) identify some of the entrepreneurship skills required by students/graduates as ability to raise and manage money, communication with customers via e-mail, phone, websites, communication with staff as well as sales skills including connecting with social media networks. In the same vein, Jones, George and Hill (2000) summarize entrepreneurship skills as follows:

Technical Skills: This refers to acquisition of job specific knowledge and techniques that are needed to function effectively in an organization role. For instance, a principal of a private school may need accountants and bookkeeping clerks to keep records of school fees payment, receipt, cost and the payroll. He may also need teachers and other staff to take care of students and keep the school environment tidy and attractive.

Human Skills: These are skills that help the individual comprehend and regulate the behaviour of other individuals or groups with the intent to promote communication and motivation, while moulding behaviours towards greater individual and team productivity.

Conceptual Skills: These skills relate to the ability to examine and analyse a situation to differentiate between cause and effect. Conceptual skills are very much required in organizational planning and administration. It takes education training and retraining to inculcate conceptual skills in workers.

According to Hisrich and Peters (1995), some other skills required by entrepreneurs can be group into three categories as follows: (1) Technical skills (2) Business management skills (3) Personal entrepreneurship skills. Business Management skills involve the establishment, nurturing and management of an enterprise as well as the skills required for effective decision making, marketing management, finance, accounting, bookkeeping and ability to keep records properly. Emphasizing the necessity of entrepreneurship skills, Buwari (2018) states that it is 
imperative that students, youths and graduates be equipped with these skills to elevate them from the present condition of indigence and joblessness.

\section{Entrepreneurship Skills Needed by Students and Graduates for Global Relevance}

According to Oluwuo (2019), Global Relevance means alignment in time with global demands. With globalization, no country is able to exist alone. Every country has to play its part to be relevant to the demands of the global economy. Ogonor (2019) maintains that global relevance involves the production of goods and rendering of services that meet international standards. This means that goods and services produced in a particular nation are of a comparative value at the international level. Thus, to compete favourably, entrepreneurship education in Nigeria must aim at global relevance. It is in this vein that entrepreneurship skills needed by students and graduates for global relevance are discussed as follows:

Accounting Skills: Accounting skills is an area of study essential for equipping recipients with the required knowledge, attitude and competency for accurate financial record keeping, occupational pursuit and other economic and organizational activities. This includes skills that enable assessment, documentation and communication of relevant economic reports to interested individuals and business concerns.

This is an area that cannot be downplayed owing to the fact that growth and stability of any business organization depends largely on adequate record keeping of its transactions. Umunnah (1992) and Ahukannah, Ndinechi and Anukwe (1989) opine that the roles of accounting skills in the operation of business enterprises include documentation and analysis of financial data, preparation of accounting statements and communication of these financial reports to employers.

Some of the accounting and financial skills needed are competence in keeping and updating accounts, competence in costing, competence in preparation and interpretation of financial statements, knowledge of sources of funds, knowledge of levies, taxes and regulation at federal, state and local government levels, knowledge of procedures for granting loan from financial houses, knowledge of accounts receivables and accounts payable, ability to process inventories, knowledge of preparation of ledgers and extraction of trial balance, ability to prepare daily cash reports, knowledge of bank reconciliation statements, competence in keeping sales and purchases records, ability to keep debtors ledgers, competence in preparing final accounts, profit and loss accounts and the balance sheet, competence in calculation of depreciation, ability to avoid extraneous expenditures and to prepare simple budget (Akpotowho and Amahi 2006; Salome 2012).

Marketing Skills: Okpan (2006) identified marketing skills which include ability to capture customers' attention and retain their patronage, ability to promote and market the organization's products, ability to study the market forces of demand and supply, ability to possess the demeanour for effective salesmanship and so on. Marketing cuts across all frontiers if effective survival is to take place in the economy. Zimmerer, Scarborough and Wilson (2009) define marketing as the activities involved in creating as well as delivering goods and services to customers. The secret to effective marketing is to be acquainted with the needs, wants and demands of your target customers and be able to act before your competitors offer them products and services that satisfy those needs. It also involves providing convenient and valuable customers' services that make you to enjoy their patronage.

Unfortunately, this has been elusive in small businesses because of the wide gap that exists between sound marketing principles and actual marketing practices. The marketing function in a business cuts across the whole organization including all aspects of the company's operation from production and finance to purchasing and hiring as well as the company's ultimate success.

As competition for customers become intensified, business owners must be cognizant of the urgent need to develop creative marketing strategies, knowing full well that the survival and success of the enterprise depends on it. An effective marketing campaign does not require huge spending on the part of the business organization.

What is needed is ingenuity, creativity and understanding of customers' buying habits. Some of the marketing skills outlined are: marketing plan evaluation and development, printing advertising programs, marketing deliverable, copy, layout and execution, direct mail, planning, testing, development and execution, trade show planning, promotion and execution, website development, public relations, marketing testing, video and multimedia, new product launches, start-ups and sales (Business Marketing Institute, 2013).

Managerial Skills: Ekpeyong and Ojo (2008) identified some management skills such as ability to plan, organize and manage small scale businesses, ability to maintain business ethics, ability to utilize market information, develop skills for effective supervision and co-ordination as well as ability to apply integrating skills. Management skills are prerequisite for effective job performance in organizations amongst employers and employees. Management skills 
are competencies obtained to enhance the process of running, directing or administering an organization. It refers primary to directing human endeavours and capabilities and co-ordinating the whole as a team through effective leadership.

However, management skills needed for effective job performance consist of various components which include:

Planning: This is the process of setting up targets or objectives to be achieved in the future and an outline of appropriate means necessary to accomplish them.

Directing: This is the exerting of influence on people to work towards the organizational goal. It has to do with interpersonal aspect of managing. It involves clarifying, guiding, teaching and encouraging employees to perform effectively, zealously and confidentially.

Controlling: It is the process of ensuring that organizational objective is actually being attained and correcting lapses where they occur. Its elements are setting standard, measuring performance, analysis of results and taking corrective measures (Roy, 2009).

\section{Information and Communication Technology Skills Needed by Students/Graduates for Global Relevance}

Information and Communication Technology (ICT) has to do with all kinds of technology used to generate, process and use information in various forms. This includes data, voice, image, and multimedia presentation which support and enhance communication. It also involves the interconnectedness of micro-electronics, computers and telecommunication which enables data, texts and video to be transmitted in any part of the world where signals can be received. The use of Information and Communication Technology (ICT) skills has ushered in great information innovations in teaching, learning, industry which makes it possible for graduates to become more involved in their work and be result-oriented. On the other land, it makes students to be active participants in the learning process, rather than just being passive learners of educational contents.

According to Okoro (2013) the following ICT skills are needed by graduates of Business Education:

1. Competence in sending e-mail

2. Ability to receive e-mail

3. Ability to use word processor to produce documents

4. Knowledge of using contra vision electronic software to create agenda

5. Ability to use the spreadsheet to do accounting jobs

6. Ability to use the internet to receive vocal messages

7. Ability to use the internet to conduct research

8. $\quad$ Skills for merging mails by adding

9. $\quad$ Skills for merging mails by deleting

10. Ability to edit texts by inserting materials on the screen

11. Skills for performing basic data processing

12. Ability to log on or shut down a computer system

13. Skills for keying in data

14. Ability to use text editing and layout

15. Ability to key in Microsoft word package

16. Ability to design and decorate typed documents using boarders

17. Skills for copying, pasting and inserting in other locations

18. Skills for opening a desktop publishing environment

19. Skills for identifying and using documents as well as formatting existing ones.

20. Skills for identifying and opening a spreadsheet

21. Ability to insert and delete figures in tables, rows and columns

22. Skills for identifying cells, arranging, re-arranging, naming or re-naming them. 


\section{Skills Needed as an Entrepreneur}

A study by Peshew (2017) identified the following as skills needed by entrepreneurs:

1. Curiosity: Great entrepreneurs are tasked to discover new opportunities, restructure their original business innovation and process. This is often a concomitant of the entrepreneur's passionate exploration of diverse business endeavours and fields of study outside his or her comfort zone.

2. Time Management: This involves pertinent efforts such as adequate priority planning, definition of milestones, execution and operation. It is however worthy of note that none of these efforts leads to progress by itself without effective project management and effective time allocation strategies that get the work done at target.

3. Strategic Thinking: This involves learning to solve organizational problems to the core by figuring out viable solutions to areas of weak results and revealing opportunities for growth.

4. Efficiency: This has to do with the need for high performance in the area of problem solving by exploring the $80 / 20$ rule and other relevant measures for producing higher results in less time. It also involves the ability to switch among different chores while progressing effectively from day to day.

5. Resilence: This involves the resolve and zeal to push on at the duty post everyday without giving into detriments such as stress, waning focus, hanging rejections, burnouts and slow progress. Resilence is vital to building a business from the scratch.

6. Communication: Ability to communicate with partners, peers, clients and others is part of the skills required by an entrepreneur. It is important that this communication should be concise and firm, not creating room for lapses.

7. Networking: Building a network facilities, business opportunities, partnership, engagements, securing sub-contractors and future employees.

\section{Statement of the Problem}

Entrepreneurship skills for global relevance is of paramount importance to the nation and the world at large. A nation that cannot provide for its citizenry will mar rather than promote the nation. Education curriculum should not focus on theories alone. Since $21^{\text {st }}$ Century is an era of digital technology, emphasis should be laid on creativity, innovation, problem solving and skills which are indispensable for navigating the contemporary global space. Students/graduates should be more spurred in order to develop and live in line with global trend. The school/curriculum should be tending towards competition of digital technology, creativity, innovation and not purely knowledge driven.

According to Alfred-Jaja, Ogonibo and Ogeibiri (2019), one of the possible causes of obvious lack of needful skills required by students and graduates is that education in Nigeria addresses only output and capacity development in solving problems. It is in this vein that Davis, Eickelman and Zaka (2013) opine that re-structured education including digital technology could foster development and global relevance. In the same vein, Akhere, Akpomudjere and Ihimenkpen (2017) also maintain that the importance of entrepreneurship skills is that it makes the individual job creator and employer of labour rather than being a job seeker.

It is in this vein that this study focuses on entrepreneurship skills needed by Nigerian tertiary institution students and graduates for global relevance.

\section{Purpose of the Study}

The main purpose of the study is to examine the entrepreneurship skills required by students/graduates for global relevance. Specifically, the study is designed to achieve the following:

1. Entrepreneurship skills needed by students/graduates for global relevance.

2. Information and communication technology skills needed by students/graduates for global relevance

\section{Research Questions}

The following research questions were raised to guide the study:

1. What are the entrepreneurship skills needed by students/graduates of tertiary institutions for global relevance?

2. What are the information and communication technology skills needed by students/graduates for global relevance?

\section{Hypotheses}

The following hypotheses were formulated to guide the study: 
1. There is no significant difference in the opinions of students and graduates on the entrepreneurship skills needed for global relevance.

2. There is no significant difference in the opinions of students and graduates on the information and communication technology skills needed by students and graduates for global relevance.

\section{Methods}

The study adopted the survey design. This is because, it is a fact-finding technique that focuses on people. According to Nworgu (2015), a survey design refers to one in which a group of people or items are studied by gathering and analysing data from a few people or items selected as a representative of the entire group.

The population of the study comprises Business Education Lecturers and students from three Polytechnics, four Colleges of Education and Delta State University, Abraka, all in Delta State. Out of this population, a sample of 110 was randomly selected, comprising 53 lecturers and 57 students. Two questionnaires were designed. The first was used to ascertain information for research question one on the entrepreneurship skills needed by students/graduates of tertiary institutions. The second was used to ascertain ICT skills needed by students and graduates for global relevance. Both questionnaires were made up of two sections. Section A comprises the personal information of the respondents while Section B was designed to ascertain information on entrepreneurship including ICT skills needed by students and graduates of tertiary institutions.

A 4 points Likert Scale was used as follows: Strongly Agreed (SD) 4 points; Agreed (A) 3 points; Disagreed (D) 2 points; Strongly Disagreed (SD) 1 point. The instruments were validated by three Business Education Lecturers from Delta State University, Abraka, Delta State Polytechnic, Ozoro and College of Education, Agbor, all in Delta State, Nigeria.

The administration of the instruments was done by the researcher with the assistance of two other persons. The data collected were analysed using mean and standard deviation for the research questions and independent samples t-test for the null hypotheses. The hypotheses were tested at 0.05 level of significance. The decision rule was that any item with a mean rating that is 2.5 and above is accepted; while below 2.5 is rejected.

\section{Results}

Research Question 1: What are the entrepreneurship skills needed by students/graduates of tertiary institutions?

Table 2. Mean rating of the entrepreneurship skills needed by students/graduates of tertiary institutions

\begin{tabular}{|c|c|c|c|c|}
\hline $\mathbf{S} / \mathbf{N}$ & Entrepreneurial Skills & Mean & SD & Remarks \\
\hline 1. & Trade show planning, promotion, and execution; & 3.48 & 0.63 & Needed \\
\hline 2. & Ability to know gross and net profit & 3.27 & 1.00 & Needed \\
\hline 3. & Ability to process inventories & 3.27 & 1.10 & Needed \\
\hline 4. & Ability to keep debtors ledgers & 3.26 & 1.00 & Needed \\
\hline 5. & Marketing plan evaluation and development; & 3.22 & 1.05 & Needed \\
\hline 6. & Ability to prepare ledgers and extract the trial balance & 3.21 & 1.15 & Needed \\
\hline 7. & Ability to prepare daily cash reports & 3.23 & 1.65 & Needed \\
\hline 8. & Ability to interpret financial statement & 3.15 & 0.89 & Needed \\
\hline 9. & Ability to know sources of funds & 3.15 & 0.84 & Needed \\
\hline 10. & $\begin{array}{l}\text { Ability to prepare final accounts, profit and loss accounts and the balance } \\
\text { sheet }\end{array}$ & 3.13 & 1.06 & Needed \\
\hline 11. & Ability to avoid unplanned expenditures and to prepare simple budget & 3.13 & 1.03 & Needed \\
\hline 12. & Ability to prepare bank reconciliation statements & 3.10 & 1.05 & Needed \\
\hline 13. & Print advertising programs; & 3.10 & 1.12 & Needed \\
\hline 14. & Ability to understand payroll and various deductions & 3.07 & 0.86 & Needed \\
\hline 15. & Directing & 3.07 & 1.06 & Needed \\
\hline 16. & Ability to acquire the skills for preparing financial statements & 3.04 & 1.07 & Needed \\
\hline
\end{tabular}




\begin{tabular}{lllll}
\hline 17. & Ability to keep sales and purchases records & 3.01 & 1.07 & Needed \\
18. & Public relations; & 2.88 & 0.42 & Needed \\
19. & Controlling & 2.88 & 1.06 & Needed \\
20. & New product launches, start-ups, and sales & 2.81 & 0.52 & Needed \\
21. & Marketing deliverables: Copy, layout, and execution; & 2.77 & 0.90 & Needed \\
22. & Knowledge of costing & 2.76 & 0.51 & Needed \\
23. & Market testing; & 2.76 & 0.56 & Needed \\
24. & Knowledge of accounts & 2.75 & 0.56 & Needed \\
25. & A knowledge of federal, state and local government levies, taxes and & 2.71 & 0.83 & Needed \\
& regulations & 2.69 & 0.63 & Needed \\
26. & Ability to process accounts receivable and accounts payable & 2.67 & 0.87 & Needed \\
27. & Ability to know how to obtain loans & 2.66 & 1.11 & Needed \\
28. & Ability to calculate depreciation & 2.59 & 0.72 & Needed \\
29. & knowledge of factors involved in decision to grant loan by financial houses & 2.59 & Needed \\
30. & Video and multimedia & 2.59 & 0.68 & Needed \\
31. & Organizing & 2.59 & 1.13 & Needed \\
32. & Direct mail: Planning, testing, development and execution & 2.55 & 0.81 & Needed \\
33. & Planning & 2.55 & 1.11 & Needed \\
34. & Web site development & 2.54 & 0.79 & \\
\hline
\end{tabular}

Table 2 shows the mean rating of the entrepreneurship skills needed by students/graduates of tertiary institutions. The result shows that the mean of the items ranged from 2.54 to 3.48, which are greater than the criterion mean of 2.50. This means that all the items were rated as needed by students/graduates.

Research Question 2: What are the Information and Communication Technology Skills needed by students/graduates for global relevance?

Table 3. Mean rating of the ICT Skills needed by students/graduates for global relevance

\begin{tabular}{lllll}
\hline S/N & ICT Skills & Mean & SD & Remarks \\
\hline 1. & Ability to create agenda using contra vision electronic & 3.27 & 1.00 & Accepted \\
2. & Aoftware & 3.27 & 1.10 & Accepted \\
3. & Ability to merge mails by deleting & 3.26 & 1.00 & Accepted \\
4. & Ability to key in data & 3.22 & 1.05 & Accepted \\
5. & Skills in editing text on the screen by inserting materials & 3.21 & 1.15 & Accepted \\
6. & Skills in producing documents with word processors & 3.15 & 0.89 & Accepted \\
7. & Skills in producing accounting jobs using spreadsheet & 3.15 & 0.84 & Accepted \\
& software & 3.13 & 1.06 & Accepted \\
8. & Ability to use text editing and layout & & Accepted \\
9. & Ability to use borders in designing and decorating a typed & 3.13 & 1.03 & \\
& documents & 3.10 & 1.05 & Accepted \\
10. & Ability to perform basic data processing & 3.10 & 1.12 & Accepted \\
11. & Ability to open a desktop publishing environment & 3.07 & 0.86 & Accepted \\
12. & Ability to receive fax messages & 3.04 & 1.07 & Accepted \\
13. & Ability to send fax messages & 3.01 & 1.07 & Accepted \\
14. & Ability to log on or shut-down a computer system & & \\
\hline
\end{tabular}


15. Ability to identify and use documents, format existing ones in the system to prepare reports, memos, invoices and letters

16. Ability to receive e-mail

2.77

0.90

Accepted

17. Ability to send e-mail

2.76

0.51

Accepted

2.75

0.56

Accepted

18. Ability to key in figures in table, rows, columns, insert additional rows and delete where necessary

2.75

1.15

Accepted

19. Skills in using tele/video conferencing

2.71

0.83

Accepted

20. Ability to merge mails by adding

2.69

0.63

Accepted

21. Ability to receive vocal messages using the internet

2.67

0.87

Accepted

22. Ability to key in Microsoft word package

2.66

1.11

Accepted

23. Skills in conducting research using the internet

2.59

0.72

Accepted

24. Ability to identify cells, arrange, re-arrange, name or rename a cell.

2.59

0.85

Accepted

25. Ability to identify and open a spreadsheet environment

2.55

0.81

Accepted

26. Ability to create website

2.51

0.79

Accepted

Table 3 shows the mean rating of the ICT Skills needed by students/graduates for global relevance. The result shows that the mean of the items ranged from 2.51 to 3.27 , which are greater than the criterion mean of 2.50 . This means that all the items were rated as needed by students/graduates.

Hypothesis 1: There is no significant difference in the opinions of students and graduates on the entrepreneurship skills needed for global relevance.

Table 4. t-test of difference in opinions of students and graduates on the entrepreneurship skills needed for global relevance

\begin{tabular}{lllllllll}
\hline Status & $\boldsymbol{n}$ & Mean & $\boldsymbol{S D}$ & $\boldsymbol{d} \boldsymbol{f}$ & $\boldsymbol{t}$ & $\boldsymbol{P}$ & $\boldsymbol{d}$ & Decision \\
\hline Students & 57 & 2.78 & 0.39 & & & & & \\
Graduates & 53 & 3.07 & 0.25 & 108 & 4.68 & .000 & 0.17 & Significant \\
\hline$\alpha=.05$ & & & & & & & &
\end{tabular}

Table 4 shows the result of an independent samples t-test, which was conducted on the difference in the opinions of students and graduates on the entrepreneurship skills needed for global relevance. The result shows that $\mathrm{t}(2.108)=$ 4.68, $\mathrm{p}<0.05$ level of significance. Hence the null hypothesis is rejected, which implies that there is a significant difference in opinions of students and graduates on the entrepreneurship skills needed for global relevance. The result further shows that graduates (Mean $=3.07, \mathrm{SD}=0.25$ ) had a higher mean than students ( mean $=2.78, \mathrm{SD}=0.39$ ) indicating that graduates need entrepreneurship skills more than students. Cohen $-\mathrm{d}$ value is 0.17 , which indicates a larger effect size when compared with the criterion of Cohen (1988).

Hypothesis 2: There is no significant difference in the opinions of students and graduates on the information and communication technology skills needed for global relevance.

Table 5. t-test of difference in the opinions of students and graduates on the information and communication technology skills needed for global relevance.

\begin{tabular}{lllllllll}
\hline Status & $\boldsymbol{N}$ & Mean & $\boldsymbol{S D}$ & $\boldsymbol{d} \boldsymbol{f}$ & $\boldsymbol{t}$ & $\boldsymbol{P}$ & $\boldsymbol{d}$ & Decision \\
\hline Students & 57 & 2.77 & 0.37 & & & & & \\
Graduates & 53 & 3.10 & 0.25 & 108 & 5.45 & .000 & 0.22 & Significant \\
\hline
\end{tabular}

$\alpha=.05$

Table 5 shows the result of an independent samples t-test, which was conducted on the difference in opinions of students and graduates on the information and communication technology skills needed for global relevance. The result shows that $\mathrm{t}(2.108)=5.45, \mathrm{p}<0.05$ level of significance. Hence, the null hypothesis is rejected, which implies that there is significant difference in opinions of students and graduates on the information and communication 
technology skills needed for global relevance. The result further shows that graduates $($ Mean $=3.10, S D=0.25)$ had a higher mean than students (Mean $=2.77, \mathrm{SD}=0.37$ ) indicating that graduates need ICT skills more than students. Cohen $-\mathrm{d}$ value is 0.22 which indicates a large effect size when compared with the criterion of Cohen (1988).

\section{Discussion}

This study investigates the entrepreneurship skills needed by students and graduates for global relevance. From the data obtained in the field, various findings emerged. The study found that the entrepreneurship skills needed by students/graduates of tertiary institutions include trade show planning, promotion, and execution; ability to know gross and net profit; ability to process inventories; ability to keep debtors ledgers; marketing plan evaluation and development; ability to prepare ledgers and extract the trial balance; ability to prepare daily cash reports; ability to interpret financial statement; and ability to know sources of funds. Others include ability to prepare final accounts, profit and loss accounts and the balance sheet; ability to avoid unplanned expenditures and to prepare simple budget; ability to prepare bank reconciliation statements; print advertising programs; ability to understand payroll and various deductions; directing; ability to acquire the skill of preparing financial statements; and ability to keep sales and purchases records.

A corresponding hypothesis revealed that a significant difference exists between the entrepreneurship skills needed by students and graduates. This finding may be as a result of the fact that more graduates, having experienced the job market during their national service year, may have realised the importance of these entrepreneurship skills and may be in need of such more than their counterparts who are still in schools, undergoing training in different undergraduate programmes. This finding agrees with the study of Jones, et al. (2000), who identified some of the entrepreneurship skills needed by graduates to include technical, human, conceptual and business management skills. The finding is also in line with Okpan (2006), who identified marketing skills, to include ability to capture customers' attention and retain their patronage, ability to promote and sell the organization's products, ability to analyse demand and supply situations, ability to possess the demeanour for effective salesmanship and so on. Ekpenyong and Ojo (2008) also identified some management skills, such as ability to plan, organize and manage small scale business, ability to maintain business ethics and ability to interpret market information, ability to develop skills for effective supervision and coordination as well as ability to apply integrating skills.

The study also found that the ICT Skills needed by students/graduates for global relevance include ability to create agenda using contra vision electronic software; ability to merge mails by deleting; ability to key in data; ability to copy, paste or insert in another location; skills in editing text on the screen by inserting materials; skills in producing documents with word processors; skills in producing accounting jobs using spreadsheet software; and ability to use text editing and layout. Others include ability to use borders in designing and decorating typed documents; ability to perform basic data processing; ability to open a desktop publishing environment; ability to receive fax messages; ability to send fax messages; ability to log on or shut-down a computer system; ability to locate and use documents, format existing ones in the system to prepare reports, memos, invoices and letters; and ability to receive e-mail.

A corresponding hypothesis revealed that a significant difference exists between the ICT skills needed by students and graduates for global relevance, with a large effect size, which implies that graduates practically need ICT skills more than students. The reason for this finding may be as result of the experience that graduates may have had during their national service year. Because most of the graduates have experienced the labour market, they may have learnt the necessity of having some of these skills, unlike their counterparts who are still in schools. This finding corresponds with the finding of Okoro (2013), who identified similar ICT skills needed by graduates of Business education programme.

\section{Conclusion}

Arising from the findings of the study, it can be concluded that indeed students and graduates need certain entrepreneurship skills as well as ICT skills that will enable them to be relevant in the global market. These skills are needed if they must contribute to the economy of the nation. Graduates as a result of their work experience need more of these skills as they may have some requisite knowledge of these skills.

\section{Recommendations}

The following recommendations are therefore made:

i. Some of these skills should be integrated into the tertiary education curriculum, so undergraduate students could be exposed to them as early as possible. 
ii. Upon graduation, graduates should enrol in some ICT institutions to acquire some of the ICT skills that are needed for global relevance.

iii. Adequate teaching period should be provided for the teaching and learning of entrepreneurship education for in-depth coverage of the scheme and goals attainment.

iv. Government should make available financial resources through granting of loan that will assist the graduates to set up their own businesses as a way of helping them to sustain the acquired skills and also make them self employed or employers of labour.

v. Government should provide necessary and relevant facilities and equipment for sound development of entrepreneurship potentials in graduates that will bring about wealth and value creation for global relevance.

\section{References}

Ademiluyi, F. L. (2007). Business competencies needed for effective entrepreneurship as perceived by fresh graduates. Business Education Journal, 4(3), 18-29.

Ahukannaah, L. I., Ndinechi, G. I., \& Anukwe, O. N. (1989). Commerce for Senior Secondary, Onitsha. Africana Feb Publisher Ltd.

Akhere, S. E., Akpomudjere, O., \& Ihimenkpen (2017). Role of ICT in enhancing entrepreneur skill needed by students/graduates of tertiary institution in Nigeria. Delta Business Education Journal, 7(1).

Akpotowho F. C., \&Amahi, F. U. (2006). Perceptions of Business Teachers Educators and Small Business Operators on Identified Critical Factors for a Successful Entrepreneurship. Business Education Journal, 5(2), 72-81.

Alfred-Jaja, S., Wellington-Ogonibo and Ogeibiri, C. (2019) Benefits of Entrepreneurship Skills Acquisition Among Undergraduates Students in Tertiary Institutions in Bayelsa State.

Business Marketing Institute (2013). The Marketing Managers Handbook Business Marketing Institute.

Buwari, G. S. (2018). Entrepreneurial Skills needed by Graduates of Agricultural Education in Snail Production for Sustainable Food Security in Bayelsa State, Nigeria. Association of Business Educators of Nigeria, Conference Proceedings, 5(1), 635-642.

Davis, N., Eickelman, B., \& Zaka, P. (2013). Restricting of Educational systems in digital Age from A co-evolutionary perspective. Journal of computers Assisted Learning, 29(5). https://doi.org/10.1111/jcal.12032

Demers, J. (2014). Five Skills Every Successful Entrepreneurial Must Master. http=/www.com/article 236128.

Ekpenyong, L. E., \& Ojo, K. (2008). The Role of Entrepreneurship Education in Poverty Alleviation- Delta Journal, 2(1), 66-71.

Federal Republic of Nigeria (2013). National policy on education. Abuja: NERDC.

Hisrish, R. D., \& Peters, M. P. (1995). Entrepreneurship starting development and managing a new enterprise. Boston: Irwin McGraw-Will.

Igbongidi, B. P. (2015). Entrepreneurship Principles and Practice. High calling outreached publications.

Ikeanyionwu, C. I., \& Ekwe, K. C. (2013). Introduction of Entrepreneurship in Junior Secondary School in Onitsha North L.G.A of Anambra State. Implications for Quality Assurance.

Jones, G. R., George, J. A., \& Hill, W. L. (2000). Contemporary management. New York: McGraw-Hill Inc.

Mario Peschew. CEO of DevriX and SME Digital Consultant on Quora. Forbes.com/sites/quora/2017/09/11.

Mgbonyebi, D. C., \& Olaniyi, V. (2019). Entrepreneurship Education. A Catalyst for Effective Economic Empowerment in South-South of Nigeria. Delta Business Education Journal, 9(2), 94-102.

Nworgu, B. G (2015) Educational Research Basic Issues and Methodology ( $5^{\text {th }}$ Edition) Nsukka University Trust Publishers.

Ogonor, B. O. (2017). Square peg in a round Hole redressing. The Anomalies of Educational Administration in Nigeria.

Ogonor, B. O. (2019). Restructuring Education for Sustainable Growth, Development and Global Relevance. A Keynote Paper Presented at the $11^{\text {th }}$ International Conference Organised by Faculty of Education, Delta State University, Abraka from $25^{\text {th }}-28^{\text {th }}$ June, 2019. 
Okereke, L. C., \& Okorafor, S. N. (2011). Entrepreneurship Skills Development for millennium Development Goals (MGFDS) in Business Education. Business Education Journal, 1(11), 83-88.

Okoro, F. N., \& Ofishe, W.O. (2011). Practical entrepreneurship. Benin City: Mindea Publishing.

Okoro, J. (2013). Assessment of information and communication technology competencies possessed by university postgraduate Business Education students to handle entrepreneurship Business challenges in Nigeria. Global Journal of Management and Business Research Administration and Management, 13(8), 43-51.

Okpan, M. O. (2006) Business Education Competencies Required for Entrepreneurship Development. Business Education Journal, 5(2), 24-31.

Oluwuo, S. (2019). Re-structuring Education for Sustainable Growth, Development and Global Relevance. A Keynote Paper Presented at the $11^{\text {th }}$ International Conference Organised by Faculty of Education, Delta State University, Abraka from $25^{\text {th }}-28^{\text {th }}$ June, 2019.

Osakwe, S. O., \& Ogona, A. U. (2019). Entrepreneurial and Sustainable Development in Nigeria. Delta Business Education Journal, 9(2), 278-288.

Patel, S. (2015). The 17 Skills Required to Succeed as an Entrepreneur= http://www.entrepreneur.com/article/242327.

Roy, R. (2009) Entrepreneurship - India Oxford University Press.

Salome, E. W. (2012). The Teacher and Skills Acquisition at Business Education. From the Perspective of Accounting Skills. Arabian Journal of Business and Management Review (OMAN Chapter), 2(4), 1-15. https://doi.org/10.12816/0002256

Umunnah, E. B. (1992). Accounting Education in Nigeria Polytechnics. Business Education Journal, 11(4), 64-71. Workshop on Entrepreneurship Conducted in East-West Centre (Honolulu, 1997)

Zimmerer, T. W., Scarborough, N. M. C., \& Wilson, D (2009). Essentials of Entrepreneurship and Small Business Management, New Delhi. Philearning Private Limited.

\section{Copyrights}

Copyright for this article is retained by the author(s), with first publication rights granted to the journal.

This is an open-access article distributed under the terms and conditions of the Creative Commons Attribution license (http://creativecommons.org/licenses/by/4.0/). 